\title{
A Sustainable Study on Permeable Concrete using Bagasse Ash and Rice Husk Ash as a Partial Replacement of Cement
}

\author{
${ }^{1}$ Dr. Vanathi*, ${ }^{2}$ Dr.K. Radhika, Ms. G. Swetha \\ ${ }^{1}$ Professor, Dept. of Civil Engineering, Guru Nanak Institutions Technical Campus, Hyderabad, Telangana, India. \\ ${ }^{2}$ Professor, Dept. of Civil Engineering, St.Peter's Engineering College, Hyderabad, Telangana, India. \\ ${ }^{3}$ Assistant Professor, Dept. of Civil Engineering, Gokaraju Rangaraju Institute of Engineering and Technology, India
}

\begin{abstract}
Permeable concrete is a special concrete which consists of cement, coarse aggregate and water. Due to rapid growth of globalization and urbanization, the construction of concrete roads increasing day by day which leads to decrease in percolation of storm water, surface runoff occurring to the decrease in ground water table. In previous concrete, single sized aggregate is used to maintain the void ratio in the concrete. The cement paste is bonded with aggregate with a void ratio of $20 \%$. In this investigation, concrete of M20 grade with water cement ratio of 0.38 is used. The properties of concrete were increased by using Rice husk ash and Bagasse ash in changed percentages $(10 \%, 20 \%, 30 \%)$ by weight of cement and with the combination of rice husk ash and bagasse ash 10\% (5\%RA + 5\%BA), 20\%(10\%RA+10\%BA), 30\%(15\%RA+15\%BA) are used. The compressive strength of cubes, split tensile of cylinders are casted, tested after 7 days and 28 days. After testing, the optimum percentages of replacement of admixtures are found in the Permeable concrete. Therefore the strength and durability properties of permeable concrete with the addition of bagasse ash and rice husk ash with partial replacement of cement are compared with conventional concrete.
\end{abstract}

\section{Introduction}

Due to construction of rigid pavements, the rainfall water in surface runoff can not be percolate in to the ground surface which leads to ground water depletion. As a rapid growth of industrialization and population, it implies the need of ground but the impermeable concrete in various applications such as road pavement and concrete structures which affect the ground water table. To over come the ground water depletion, the solution is Permeable pavements which percolates the runoff from rain and storm water and which increase the ground water table and aquifers to make the sufficient water for sustainable use.

Due to usage of cement in constructions, it releases $\mathrm{CO}_{2}$ and which effects the environment. The emission of $\mathrm{CO}_{2}$ can be minimized by using eco-friendly materials. i.e., byproducts from Rice and sugar industry.

Bagasse ash and Rice Husk Ash have pozzolonic property, which is about $62 \%$ and $90 \%$ silica dioxide $\left(\mathrm{SiO}_{2}\right)$ can be utilized as limited replacement with cement. Kawade et al [1] studied that utilization of bagasse ash will increase its strength up to $15 \%$ with replacement of cement beyond its limits it start decreasing its strength properties. Srinivasan et al [2] studied that bagasse residue, after combustion produces a chemical composition of silica dioxide which can be used as partial replacement. Pitroda et al, [3] in his experimental study, the effect of Rice Husk Ash properties of Permeable concrete with various $w / \mathrm{c}$ ratios $0.3,0.36,0.40$; the compressive \& flexural strength varies depending upon the w/c ratio. It has been shown that up to $10 \%$ replacement of RHA is increased beyond it starts decreasing.

\section{Objective}

- To control the emission of $\mathrm{CO}_{2}$ through partial replacement of cement by using agricultural waste.

- To enhance the strength and durability of Permeable concrete and to make an ecomaterial for road pavement.

- To minimize the waste, reduce disposal problems, reduce cost and also to produce green material.

- To increase ground water table by improving the permeability of concrete.

\section{Experimental Materials}

\section{Cement}

It is a mineral powdered material binds easily when mixed with water .which act as a binder material in construction works. In this investigational work, an OPC cement of 53 grade is used. IS: 12269 - 1987, "Specifications for 53 grade ordinary Portland cement", Bureau of Indian Standards, New Delhi [7].

\footnotetext{
*orresponding author: flytovans@yahoo.co.in
} 


\section{Coarse Aggregate}

Single Size aggregate are used passing from $20 \mathrm{~mm}$ IS Sieve retained on $9.5 \mathrm{~mm}$ sieve. Aggregate plays a major role in gradation, compressive strength, permeability. Uniformly graded aggregate gives higher compressive strength as well as higher void content. Sourabh Rahangdale et al, $[4\}$ in their investigation of study shows that aggregate between $12.2-16 \mathrm{~mm}$ size of aggregate having much higher compressive strength \& the split tensile strengths are good and the permeability properties as well.

\section{Rice Husk Ash}

India is a major paddy producing country. Annually, nearly 2,00,00,000 tonnes of rice husk ash is produced. Which creating a disposing problem and causing damage to environment. Rice Husk Ash has a pozzolonic properties so which can be used as cementious material up to certain percentage beyond it start losing its strength properties.

Table 1. Chemical properties of Rice Husk Ash.

\begin{tabular}{|l|l|}
\hline Chemical Properties & \% \\
\hline Silicon dioxide $\left(\mathrm{SiO}_{2}\right)$ & 90.7 \\
\hline Aluminium oxide $\left(\mathrm{Al}_{2} \mathrm{O}_{3}\right)$ & 0.4 \\
\hline Ferric oxide $\left(\mathrm{Fe}_{2} \mathrm{O}_{3}\right)$ & 0.4 \\
\hline Calcium oxide $(\mathrm{CaO})$ & 0.4 \\
\hline Magnesium oxide $(\mathrm{MgO})$ & 0.5 \\
\hline Sodium oxide $\left(\mathrm{Na}_{2} \mathrm{O}\right)$ & 0.1 \\
\hline Potassium oxide $\left(\mathrm{K}_{2} \mathrm{O}\right)$ & 2.2 \\
\hline quivalent alkali $\left(\mathrm{Na}_{2} \mathrm{O}+0.658 \mathrm{~K}_{2} \mathrm{O}\right)$ & 1.5 \\
\hline Phosphorous oxide $\left(\mathrm{P}_{2} \mathrm{O}_{5}\right)$ & 0.4 \\
\hline Itanium oxide $\left(\mathrm{TiO}_{2}\right)$ & 0.03 \\
\hline Sulphur trioxide $\left(\mathrm{SO}_{3}\right)$ & 0.1 \\
\hline Loss of ignition & 4.8 \\
\hline
\end{tabular}

\section{Bagasse Ash}

Bagasse ash is a by-Product of sugar factory. India is the second largest country to producer of sugar cane of about 29.5 million tonnes causing the disposal problem. It can be minimized by partial replacement of cement.

Table 2. Chemical properties of Bagasse Ash

\begin{tabular}{|l|l|}
\hline Chemical properties & $\%$ \\
\hline Silicondioxide $\left.\left(\mathrm{SiO}_{2}\right)\right)$ & 62.42 \\
\hline Aluminium oxide $\left(\mathrm{Al}_{2} \mathrm{O}_{3}\right)$ & 4.39 \\
\hline Ferric oxide $\left(\mathrm{Fe}_{2} \mathrm{O}_{3}\right)$ & 6.99 \\
\hline
\end{tabular}

\begin{tabular}{|l|l|}
\hline Calcium oxide $(\mathrm{CaO})$ & 11.81 \\
\hline Magnesium oxide $(\mathrm{MgO})$ & 2.52 \\
\hline Potassium oxide $\left(\mathrm{K}_{2} \mathrm{O}\right)$ & 3.54 \\
\hline Sulphur trioxide $\left(\mathrm{SO}_{3}\right)$ & 1.46 \\
\hline Loss of ignition & 4.72 \\
\hline
\end{tabular}

\section{Methodology}

Permeable concrete is also known as porous. It consists of cement, aggregate and water in different proportions (1:2, $1: 4,1: 6)$ with a void ratio of $20 \%$. Gaurav uttam shinde [5] studied that with increase in void ratio, infiltration increases besides decease in compressive strength and vice versa. Ajamu et al [6] the study shows with 1:6 Aggregate to cement ratio, the highest compressive strength was observed when compared to $1: 8$ and $1: 10$ ratios. From the optimum proportion of admixture the results are found. In this investigation, M20 grade of concrete with 0.36 water-cement ratio is used. The cubes are casted and tested with different percentages of $(10 \%$, $20 \%$, and $30 \%$ ) by cement weight using rice husk ash, bagasse ash and the combination of both. Besides, Compressive strength tests and split tensile strength tests, permeability tests are also considered in permeable concrete and compared with conventional concrete.

\section{Experimental Study}

The permeable concrete behavior with various types of proportion is studied through an experimental programme. The different mix proportion such as $(1: 2$, $1: 4$, and 1:6) have been prepared and tested through M20 concrete grade with W/C ratio 0.36 From IRC: 44-2017, "Guidelines For Cement Concrete Mix Design For Pavements". [8] The three samples are casted for each mix proportion to find the performance of Permeable concrete. After casting, the specimens are tested using compression testing machine, to evaluate the compressive strength of concrete. The split tensile strength of cylinders was determined for dimensions of $300 \mathrm{~mm} \times 150 \mathrm{~mm}$ sample by testing with Universal Testing Machine. In addition to this, the permeability for designed Permeable concrete is tested and compared with conventional concrete.

\section{Results and Discussion}

The behavior of previous concrete with various types of proportion is studied through an experimental programme. The different mix proportion such as $(1: 2$, $1: 4$, and 1:6) have been prepared and tested through M20 concrete grade with w/c ratio 0.36 From IRC: 44-2017, "Guidelines For Cement Concrete Mix Design For Pavements". [8] The three samples are casted and tested for each mix proportions to find performance of Permeable concrete. After casting, specimens are tested for compressive strength and split tensile strength of concrete. In addition to this, the durability properties such as permeability for designed Permeable concrete is tested and compared with conventional concrete. 


\section{Compressive Strength}

Compressive strength results of Permeable concrete is determined for 7 days and 28 days. The following graphs were drawn with respective $\%$ of replacement $\mathrm{v}_{\mathrm{s}}$ compressive strength.

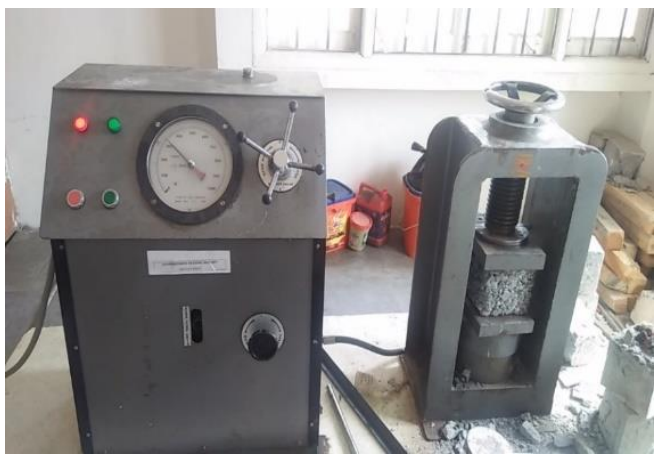

Fig. 1. Compressive strength test on cube specimen

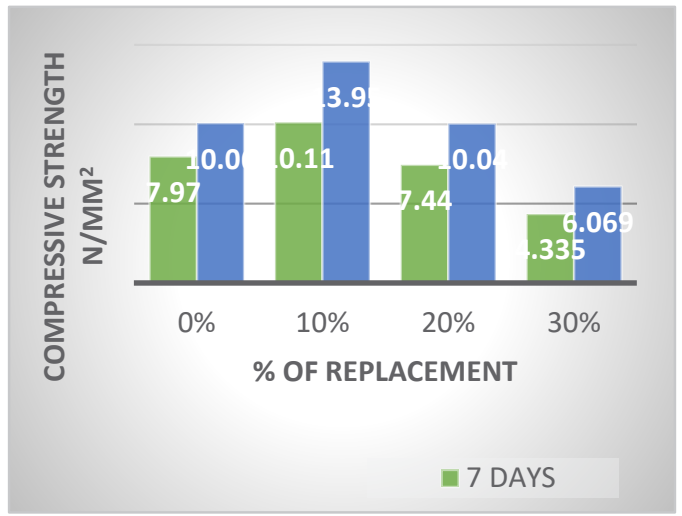

Fig. 2. Rice Husk Replacement Ash with Cement

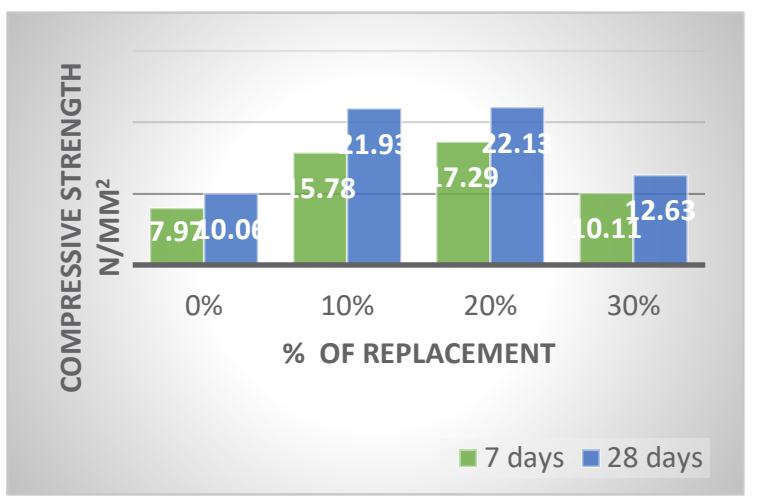

Fig. 3. Bagasse Ash Replacement with Cement

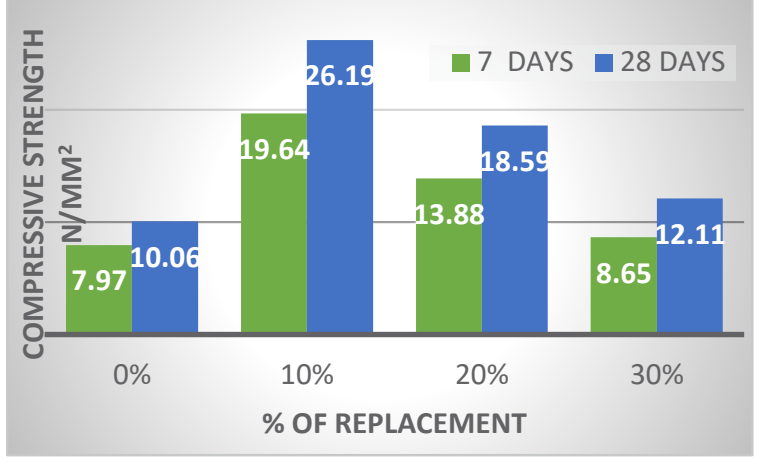

Fig. 4. Rice Husk Ash and Bagasse ash Replacement with Cement

\section{Split Tensile Strength}

Split tensile strength is conducted for cylinder of dimensions 300x150mm from optimum percentage of admixture found during compressive strength of cubes. Test results are for 7 days $2.02 \mathrm{~N} / \mathrm{mm}^{2}$ and for 28 days 2.74 $\mathrm{N} / \mathrm{mm}^{2}$

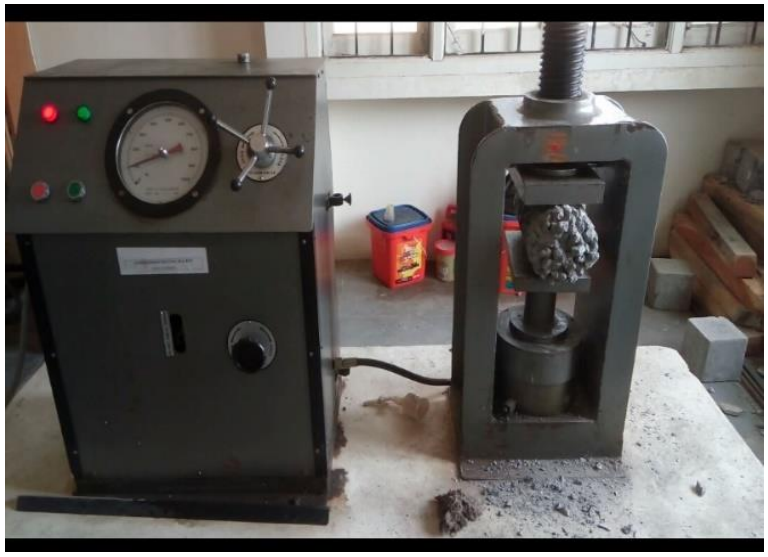

Fig. 5. Split tensile strength on Cylinder specimen

\section{Permeability Test}

Permeability test are conducted on the Permeable concrete, the rate of water flow from Permeable concrete is 700 litre/hr/sq.m

\section{Conclusion}

In this experiment, the durability and permeability properties of Permeable Concrete has studied when the cement is replaced with Rice Husk Ash and Bagasse Ash in different percentages. The results shows that, the Compressive Strength is optimum at $10 \%$ $(5 \%$ RHA $+5 \% \mathrm{BA})$ replacement of cement with mixture of Rice Husk Ash and Bagasse Ash and strength increse is mainly due to the occurrence of more amount of Silica presence in Rice Husk Ash and Sugarcane Bagasse ash. Hence, it is a cost effective and environment friendly construction used for the sustainable use. 


\section{References}

1. Kawade, U.R., Rathi, V.R. Vaishalid G., "Effect of Use Bagasse ash on strength of Concrete," International Journal of Innovative Research in Science, Engineering and Technology, Vol. 2, Issue 7. 2013. pp.2997-3000 ISSN: 2319-8753.

2. Srinivasan and Sathiya, K., "Experimental Study on Bagasse Ash in Concrete" International Journal for Service Learning in Engineering, Vol. 5, No. 2, 2010, pp.60-66, ISSN 1555-9033.

3. Pitroda et al., "Effect of Rice Husk Ash on Properties of Permeable Concrete", International Journal of Advanced Engineering Research and Studies, March, 2015.

4. Sourabh Rahangdale, shobhit maran, sumit lakhmanil, mayuresh gidde "Study of Permeable Concrete", IRJET, Volume 4, Issue 6, June 2017.

5. Gaurav uttam shinde, "An Experimental study on Compressive strength, Void Ratio and Infiltration Rate of Permeable concrete."

6. Ajamu S.O., Jimoh, A.A and Oluremi, J.R., "Evaluation of Structural Performance of Permeable concrete in construction ". International Journal of Engineering and Technology, Volume 2(5) May 2012, pp.825-836.

7. IS: 12269 - 1987, "Specifications for 53 grade ordinary Portland cement", Bureau of Indian Standards, New Delhi.

8. IRC: 44-2017, "Guidelines For Cement Concrete Mix Design For Pavements".

9. American Concrete Institute (ACI) Committee 522, "Report on Permeable Concrete", ACI 522R-10, American Concrete Institute, Farmington Hills, Michigan, USA, 2010.

10. Anubhav Rai et al., "Application of Different Agricultural Waste in Concrete as a Partial Replacement of Cement", Volume 5, Issue 2, April 2018-ISSN No 2348-8565. 